\title{
Parallels of Love in Rumi and Donne
}

\author{
Mohammad Reza Modarres Zadeh (Corresponding author) \\ Shiraz University, Iran
}

Alireza Anushirvani

Shiraz University, Iran

Received: 25-08-2016

Accepted: 29-09-2016

Published: 31-10-2016

doi:10.7575/aiac.ijclts.v.4n.4p.24

URL: http://dx.doi.org/10.7575/aiac.ijclts.v.4n.4p.24

\begin{abstract}
In this article, we compare certain aspects of the love poetry of Jalāl al-Dīn Rūmī (1207-1273), the most distinguished Sufi mystic and poet of the Persian language, and John Donne (1572-1631), the leading English poet of the Metaphysical school. Despite the cultural and age difference between the 13th century Persian Sufi and the English Christian poet of the Renaissance, there are striking similarities in their experience of love as revealed in their poetry. For both, love stands unique in the universe, creates a new status of self, engages lover and beloved in perfect union, obliterates temporality, integrates both body and soul and climbs to the heights of Divine jealousy. The two poets are worlds apart but the world of love to which they take their reader is essentially the same.
\end{abstract}

Keywords: Rumi, Donne, love, comparative literature

\section{Introduction}

"At the touch of love everyone becomes a poet."

- Plato

"We are defined only by comparing ourselves to others; we do not know ourselves only when we know only ourselves."

- Ferdinand Brunetiere, "European Literature."

Hamlet is certain about love. "Doubt that the stars are fire," he writes to Ophelia, "Doubt that the sun doth move his aides, Doubt truth to be a liar, But never doubt I love" (Hamlet 2.2.1212=15). Ferdinand, the King of Navarre, is, initially, not so certain, but he too reaches a similar conclusion when the Princess of France arrives "And," as Berowne would have it, "when love speaks, the voice of all the gods makes heaven drowsy with the harmony" (Love's Labour's Lost, 4.3.1689-90). Love has been revered time and again in a variety of voices. Oscar Wilde looks to the emotional side of life when he advises "Keep love in your heart. A life without it is like a sunless garden when the flowers are dead. The consciousness of loving and being loved brings warmth and richness to life that nothing else can bring" (1952, p.102) while Thomas Carlyle weds the mind to the heart with the assertion that "A loving heart is the beginning of all knowledge" (2010, p.57). In a similar vein, Carl Sagan makes the heart a sanctuary for the mind, believing that "For small creatures such as we the vastness is bearable only through love" (1997, p.430). The experience of love is not always enchanting, but, as Tennyson reassures, worthwhile even at the cost of pain: "I feel it, when I sorrow most / Tis better to have loved and lost / Than never to have loved at all" ("In Memoriam," 14-16). C.S. Lewis, the memorable authority on love, sums it all up when he states that "Affection is responsible for nine-tenths of whatever solid and durable happiness there is in our natural lives" (1960, p.80). Knowing the true meaning of love is a gift which can pave the way to the experience of love which, in turn, is a virtue no one should be refused. And the most beautiful panorama of love is the domain of literature.

Great literature is the manifestation of heartfelt experience and if there may arise doubt in all other inlets of truth, this is the exception. Literature portrays man to himself and comparison in literature perfects the image to utmost vividness. S. S. Prawer believes comparative literature to be "an examination of literary texts in more than one language through an investigation of "contrast," "analogy," "provenance" or "influence" (1973, p.8), and as concerns the method of comparative literature states: "comparative literature does not in itself commit one to any other principle than that comparison is a most useful technique for analyzing works of art and that instead of confining comparisons to writings in the same language, one may usefully choose points of comparison in other languages" (p.12). The focus of the present article is the comparison of the two great poets Jalāl al-Dīn Rūmī and John Donne.

The love poetry of Rūmī has been compared to that of Donne by Mannani (2004). Mannani focuses most prominently on the contrasts she argues for in the love poetry of the two poets. She maintains that, in contrast to 
Rumi, Donne's divine love poetry is entangled with a sense of obligation. She also highlights the cynicism imbued in the poetry in which Donne targets women contrasting it with the poetry of Rumi whose aim, she maintains, is the compassionate address of all humankind. In addition, she contrasts the eroticism seen in Donne's Songs and Sonets with that of the Masnavi and Divan-e Shams (Rumi's two masterpieces), finding Rumi's eroticism, in contrast to Donne's, a common, accepted means of presenting the relationship of love between man and God. She finds similarity between the two poets in their treatment of love on the two levels of sensuality and (spiritual) attachment between lover and beloved. Rumi has also been compared to Walt Whitman. Fayez (1978) argues that it is the eroticism of the soul or the self which establishes a striking closeness between the poems of Rumi and Whitman. He maintains that the carnal imagery used by Whitman to convey other than carnal desire is also the imagery of mystical love which is frequently common in the Sufi-oriented poetry of Rumi.

In this article, we compare selections of the poetry of Jalāl al-Dīn Rūmī and John Donne in an attempt to illuminate the true meaning behind the word "love." Despite being cultures and ages apart, the two poets show a remarkable similarity in terms of the various aspects of love shimmering behind the dazzling beauty of their verse. This similarity engages us with a human emotion stripped of time and place and all embellishment, taking us deep down into the world of Jung's collective unconscious that "consists of preexistent forms, the archetypes, ... which give definite form to certain psychic contents" (as cited in De Coster, 2010, p.3), and whose most precious gem is, most possibly, this very emotion: love.

\section{The Importance of Love in Rumi and Donne}

Rumi and Donne both attribute uniqueness to the status of love and entrust it with the highest pinnacle of being. Love furnishes existence with a meaning without which there is nothing but vacancy. It creates, exclusively, a certain status of "self" in man, a new and unique version of self. This love-intoxicated status of self, is so similar in both poets that the wide stretch of age and cultural difference between them - Rumi being a $13^{\text {th }}$ century Sufi poet in a predominantly Islamic nation and Donne a Renaissance poet of the Christian world - seems to dissolve, leaving only an unfettered human essence. In the world of Rumi, love is the basis of all existence stretching from the material to the heavenly world, and from the void of timelessness to the reality of past and present. It is not a choice. Nor is it to be desired or dismissed at will. Love was preordained to be part of universal fate, since "The Wisdom of God in destiny / and in decree made us lovers of one another," and thus "Because of that fore-ordainment all the particles of the world / repaired as mates and are in love with their own mate" (Masnavi, Book 3: 4400-01). ${ }^{1}$ The particles of the universe are engaged in a cosmic movement whereby they participate in an all-encompassing attraction of love which spans the totality of being. The fact that "God put desire in man and woman / in order that the world should be preserved by this union (Book 3: 4415) is an obvious given, but in Rumi's world, visionary lovers and beloveds such as thirst and water also seek each other to form the union of love:

$$
\begin{aligned}
& \text { The thirsty man is moaning, "O delicious water!" } \\
& \text { The water moans too, saying, "Where is the water-drinker?" } \\
& \text { This thirst in our souls is the attraction exerted by the Water: } \\
& \text { we are Its, and It is ours. (Book 3: 4398-99) }
\end{aligned}
$$

Apparently, long before evolution ordained that water should quench thirst, love had preordained that the two were to move along its path so as to finally meet in its union. We are, ultimately, in a universe whose warmth comes from the waves of love: "Know that the wheeling heavens are turned by waves of Love / were it not for Love, the world would be frozen" (Book 5: 3854).

Donne's view of love can be seen in the treatment of women in his poetry, an option not open to Rumi because of the cultural taboos on any demonstration of male - female relations in public within Islamic nations. When Donne wonders what he did before he loved, the exceptional significance of love in his world becomes evident. The first stanza of "The good-morrow" resounds with clarity:

I wonder by my troth, what thou and I

Did, till we lov'd? Were we not wean'd till then,

But suck'd on country pleasures, childishly?

Or snorted we in the seven sleepers' den?

'Twas so; but this, all pleasures fancies be.

If ever any beauty I did see,

Which I desir'd, and got, 'twas but a dream of thee. (1-7)

With the advent of love into his world there comes the realization that all else is merely "child play." The poet realizes he was not living before loving, he was sleeping; he realizes that other than love there exists no true pleasure, "all pleasures fancies be." All beauties are but images of love which deem beauty until love arrives and beauty is eclipsed by its true origin. For Donne, love awards a unique joyous transcendence which demarcates its boundaries and shuts out all else; it is "an antidote to the impermanence and mortality that characterize the rest of the world" (Guibbory, 2006, p.138). Love does not suffer either impermanence or mortality for "Whatever dies, was 
not mix'd equally / If our two loves be one, or, thou and I / Love so alike, that none do slacken, none can die" ("The good-morrow," 19-21)

\section{The Two "Selves" in Rumi and Donne}

In extension of the catholic love espoused by Rumi, the particular human spiritual love, specifically courts the union of man and the heavenly beloved - which in Rumi is not necessarily the orthodox God of religious experience, as can be seen throughout the Divan-e Shams where Shams, his mentor, is the manifestation of the heavenly beloved and the object of his love. Such a union is the fulfillment of the highest possible human potential. The advent of this love creates a certain status of "self."

Man has two selves from Rumi's perspective: a conscious, reasoning self and a potentially annihilated self. Paradoxically, it is the latter that constitutes the true essence of man, not the reverse. In normal circumstances the individual is conscious of his being and lives according to the dictates of his reasoning. Traditionally, this individual is not necessarily egoistic nor has he chosen the wrong tool to guide him in life. In Rumi's world, this is the case in both instances. The "partial reason," as Rumi calls it, "is a denier of Love / though it may give out that it is a confidant" (Book 1: 1982). He admits that "It is clever and knowing," yet laments that "it is not non existent" and for him "until the angel has become non existent, he is a Devil" (Book 1: 1983). There is a wide gap of distrust between Rumi and logic in the domain of love.

Addressing the individual who lives based on the dictates of (partial) reason, Rumi asks "Since your life has passed in travelling on land / now mountain, now river, now desert / From where will you gain the Water of Life [everlasting life]?” (Book 1: 573-74). Traveling on land symbolizes a life without (spiritual) love and (drinking from) the "water of life" includes the fluidity of spiritual freedom driven by the waves of love. "The waves of earth are our imagination and understanding and thought / the waves of water are self-effacement and intoxication and [the freedom of the] death [of self] (fana)" (Book 1: 575). Living in connection with the "imagination and understanding and thought" is one kind of life, and a burdensome one, which deprives the individual of a fluid life driven by "the waves of water" since "While you are in this intoxication, you are far from that intoxication / while you are drunk with this, you are blind to that cup" (Book 1: 576). Being "drunk with this" confines the individual within the limits of egotistical self. Living a true life involves a different kind of self.

The true self in which Rumi believes, is presented in a pun in the very first line of the Masnavi. "Listen to the reed how it tells a tale / complaining of separations" (Book 1: 1). The word "ney" (/neI/) signifying the reed can also be pronounced "ni" (/nI/) implying "absence" or "nothingness." The reed which is complaining of separations, being hollow on the inside is, per se, an "absence," a "nothing." It must be played to come alive, hence its complaint. For Rumi, living within the confines of self-awareness and the dictates of partial reason is imprisonment, since "This world is the prison, and we are the prisoners," and his solution, to "dig a hole in the prison and let yourself out!" (Book 1: 982). It is with the advent of (spiritual) love that the individual can become "nothing" himself and independent of partial reason, or, as Rumi puts it, "When the lover is fed from himself with pure wine / there reason will remain lost and companion less" (Book 1: 1981). In this state, the experience of pure joy is available because the imprisoning self has been annihilated:

When they are freed from the hand of self, they clap a hand;

when they escape from their own imperfection, they make a dance.

From within them musicians strike the tambourine;

at their ecstasy the seas burst into foam.

You see it not, but for their ears

the leaves too on the boughs are clapping hands. (Book 3: 97-99)

Thus we have two manifestations of self: the self that "travels on land" guided by understanding and thought and is "blind" and the self that, having lost its centrality, its autonomy, finds a new being in love.

In Donne's Songs and Sonets two kinds of speaker can be discerned: the speakers of the Ovidian, libertine poems who are distant from their desire and in whose poems women are debased, and the speakers who embrace their desire and especially value woman (Guibbory, 2006, p.138). "Loves Alchymie," one instance of the first group of poems, rejects the association of love with perfection and dismisses the notion of finding joy in love:

Drawing an analogy between love and alchemy, boasting of his sexual experience as he claims that no one has "deeper digg'd loves Myne then I" (1), the speaker concludes that there is no "centrique happiness" (2) or perfection to be found in love. Bitter and mocking, he attacks those who glorify their experience; the "dreame" (11) of love contrasts with the disappointing reality. (p.137)

The speaker of the poem equates love with sex, preferring the "misogynous dismissal of women as mere bodies, inert matter" (p.137). The male speaker of "Communitie" also views women as objects without value first to be possessed and then discarded (p.137). Other such poems take the same direction. The speaker in "The Indifferent" has a sensual interpretation of love, claiming that "I can love her, and her, and you and you" and dismisses any purity in amorous feelings with the qualification "I can love any, so she be not true" (8-9). In these poems a cold 
logic dictates how the speaker should manage his amorous affairs. However, this is as far as logic can comprehend any meaning and beyond callous sex life, loses its validity.

Like Rumi, Donne seems to end on a note of distrust in logic. In "Holy Sonnet II" after expressing his possession by God, "I am Thy son, made with Thyself to shine / Thy servant, whose pains thou hast still repaid" (6), he infers logically that God should intervene between him and the devil:

Except thou rise and for thine own worke fight,

Oh I shall soone despaire, when I doe see

That thou lov'st mankind well, yet wilt'not chuse me,

And Satan hates mee, yet is loth to lose me. (11-14)

Donne here needs to understand logically why his loving God will not choose him whilst the hating devil is "loath to lose" him, otherwise he will "soon despair." This questioning continues in "Holy sonnet IX" where he states:

If poisonous minerals, and if that tree

Whose fruit threw death on else immortal us,

If lecherous goats, if serpents envious

Cannot be damned, alas, why should I be? (1-4)

He reaches a level of "despair" in the lines that follow with the contention that:

Why should intent or reason, born in me,

Make sins, else equal, in me more heinous?

And mercy being easy, and glorious

To God, in His stern wrath why threatens He? (5-8)

It is a general theme of the Holy Sonnets, Altizer believes, that "Donne seem[ed] to need to unravel, to understand logically the mysteries of Christian faith. And he want[ed] to know exactly where he [stood] in relation to them" (as cited in Mannani, 2004, p.168). His immediate answer in the next line of "Holy sonnet IX" deviates from logic, situating him in a position of reverence: "But who am I, that dare dispute with thee" (9). And in "Holy Sonnet XIV" he shuns reason altogether: "Reason, your viceroy in me, me should defend / But is captiv'd, and proves weak or untrue" (7-8) and expressing his heartfelt emotion with "Yet dearly'I love you, and would be lov'd fain / But am betroth'd unto your enemy" (9-10) concludes "Take me to you, imprison me, for I / Except you'enthrall me, never shall be free" (12-13) reiterating what he longed for at the beginning of the poem:

Batter my heart, three-person'd God, for you

As yet but knock, breathe, shine, and seek to mend;

That I may rise and stand, o'erthrow me, and bend

Your force to break, blow, burn, and make me new. (1-4)

"Donne" writes Husain, "not only distrusted the power of intellect as an absolute entity not liable to error, but he also believed that faith came not through intellectual conviction but through the working of grace" (as cited in Mannani, 2004, p.90).

Moving in the totally reverse direction, certain of Donne's speakers present the experience of love as the most interesting and the most important part of life in the Songs and Sonets (Guibbory, 2006, p.140) and with these poems "we seem to have entered another world" (p.137). In the "The Extasie" we enter a world where "soules negotiate" (17); where "If any, so by love refin'd / That he soules language understood / And by good love were growen all minde" (21-23), were to chance upon the negotiation of souls in love, would "part farre purer than he came" (28). In "The good-morrow" the loving speaker makes a discovery about himself which dwarfs the accomplishment of the sea-discoverers: "Let sea-discoverers to new worlds have gone" (12) he asserts in total satisfaction of having, and being one world unto himself. "There is a sense of completion, as if the lover has finally found what was missing from life, his other half" (p.141). In the other "mutual" love poems, circles, images of perfection and wholeness distinguish the domain of love from the fragmentation and corruption in the world (p.141).

Thus in Donne two different kinds of speaker, present two different kinds of self. We have the speakers in the Ovidian poems estranged from (spiritual) love, obsessed with only sex as a matter of the body engaging one version of self, and the speakers of poems such as "The Canonization" where "Donne's figurative language makes sexual love sacred, suggesting that it offers an experience of transcendence, a taste of the divine" (Guibbory, 2006, 143), engaging another. There is a "profound interconnection of secular and sacred experience in Donne's work" (Wilcox, 2006, p.150); addressing his mistress in endearing expressions of love is not a simple matter of amorous male female relationship, it is Donne capturing "the feeling of those rare moments in (new?) love, when it seems that a world has opened, that nothing else matters, that this is perfection" (Guibbory, 2006, p.141). Moving from the libertine poems to the mutual love poems, the "autonomy" and "self-possession" of Donne's speakers (p.141) gives way to a world in which the autonomy is brought about by the selfless rule of love. "Donne is keenly aware of the 
instability of desire .... Yet a few of Donne's love poems imagine desire as fulfilled and, miraculously, persisting, as if in defiance of natural laws" (p.141). It may be said that in these poems the logical, reasoning self, transcends the natural laws with which it complies, and reveals a new self. In the "The Canonization," lover and beloved, male and female, "dye and rise the same" (26); that is, rising no longer male or female as the phoenix, they are reborn something entirely new (Bell, 2006, p.213).

\section{Perfect Union in Love}

As we engage with the work of Rumi and Donne we encounter other similarities in important aspects of their love poetry. In Donne's "The Extasie," Hadfield (2006) points out, the experience of the lovers is estranged from what are normally known to be the rules of physical reality. Here we have such pure refinement in love that the couple can go beyond the constraints of their bodies: "Our soules, (which to advance their state / Were gone out,) hung 'twixt her, and mee $(15,16)$. In this state "[t]he lovers are united and become one through their perfect union. They do not even need to speak, so advanced is their state of love that their souls can communicate" (p.61). In the words of Donne himself, "Love is a possessory Affection, it delivers him that loves into the possession of that that he loves; it is a transmuting Affection, it changes him that loves, into the very nature of that that he loves, and he is nothing else" (as cited in Mckevlin, 1973, p.65). Thus, Donne finds perfect union with his beloved as if their two bodies share one soul, or, put differently, in the manner of their two bodies and two souls being indiscriminately in possession of one another. Rumi also becomes inseparably one with his beloved in much the same manner. In a qazal he asks Shams, his mentor and initiator into the realm of spiritual love, of Shams' identity and is answered by "himself:" "I said oh Shams Tabrizi who are you? / he said I am you, I am you, I am you" (Divan-e Shams, 1526.12). ${ }^{2}$ His famous anecdote of the house that cannot contain two "I's" is another instance of how love wipes away all blemishes of distinction replacing it with perfect union. A person goes to the house of a beloved friend, knocks on the door, and having been asked who was there "He answered, 'I.' The friend said, 'Go, It is not the time / at a table [laden with cooked food] like this there is no place for the raw.' "In Rumi's world, this would-be guest has an ego, is thus a hypocrite to love, and "Save the fire of absence and separation, who will cook the raw one? / Who will deliver him from hypocrisy?" (Book 1: 3057-58) He goes away and for a year "burns" in separation and longing. After a year he is back:

$$
\begin{aligned}
& \text { He knocked at the door with a hundred fears and respects, } \\
& \text { lest any disrespectful word might escape from his lips. } \\
& \text { His friend called to him, "Who is at the door?" } \\
& \text { He answered, "It is you are at the door, O charmer of hearts." } \\
& \text { "Now," said the friend, "since you are I, come in, O myself: } \\
& \text { there is not room in the house for two I's. (Book 1: 3061-63) }
\end{aligned}
$$

The status of love, is one of selfless union.

\section{Love, Beyond Time and Place}

In their unique love-bound world neither of the two poets sees what is normally seen in the outside world. They take no heed of the temporality, fragmentation or corruption which are part of everyday life. It is as if time stands still and location dissolves; self, time and place which normally give the sense of being lose all significance and love defines a "new" being. A being which, having gone beyond itself, does not define itself according to its time or its place relative to other bodies but as a manifestation of the everlasting, unified "now" of love.

In Rumi, with the entering of self into annihilation and the domain of love, the light originating beyond appearances from the spiritual sun, is the light which illuminates the light of the heart and the true meaning of life: ${ }^{3}$ "Again, [as with the light of the eye] the light which gives light to the heart is the Light of God / which is pure and separate from the light of intellect and sense" (Book 1: 1127). This light comes from "the spiritual Sun, which is beyond the ether" and "has no peer in the mind or externally" (Book 1: 121). A sun which "strikes on the body from the quarter / where place does not exist" (Book 1: 1026); an "everlasting sun" which "has no yesterday" (Book 1: 119). In this domain and illuminated by this light, the inner, true life exits time and place; it has no need of yesterday, nor any concern of tomorrow: all location is here, all time is now. "Nothing else is" ("The Sun Rising," 22).

Donne's world of love also transcends time and place. His "The Anniversarie" is proud that everything

Is elder by a yeare, now, then it was

When thou and I first one another saw:

All other things, to their destruction draw,

Only our love hath no decay

This, no tomorrow hath, nor yesterday. (4-8)

"The experience of love - transcendent, durable - contrasts with the mutable public world, dominated by time" (Guibbory, 2006, p.140). Seasons, hours, days, and months are the "rags of time" ("The Sun Rising," 10) outside of love which, being of no consequence, "the sun must cease to define" (Wilcox, 2006, p.156) since "Love, all alike, 
no season knows, nor clime" ("The Sun Rising," 9). "Love 'makes one little roome, an every where' ("The goodmorrow,' 11); its walls become the 'spheare' of the sun, while the lovers' bed remains its 'center' ('The Sunne Rising,' 30)” (Guibbory, 2006, p.141).

\section{Love in Body and Soul}

A significant issue in the love poetry of Donne is that body and soul are not separated; rather, love presents itself in the integration of the two. In "The Extasie," we see how love engages both the body and the soul (Guibbory, 2006). In the first part of the poem the lovers" "soules," have "gone out" (15-16) of their bodies as the lovers lie on a "pregnant banke" (2) in spring. In their total rapture the "mixt soules" of the lovers have been "mixe[d] againe" by "Love," making "both one" $(35,36)$. Yet their souls are not wholly independent but must "turne" to their "bodies" (69). "Only through the material ('ayre,' 58, or 'bodies') can souls 'flow' (59) into each other. 'Loves mysteries in soules doe grow, / But yet the body is his booke' (71-72)" (p.142). In his poetry, Donne finds love "an eternal and universal pattern involving both body and soul" (Flynn, 1995, p.103)

In the love poetry of Rumi also, body and soul complete each other. Rumi's cultural milieu is worlds apart from that of Donne and yet the essence, as regards the integration of body and soul in love, is the same. The material/spiritual integration is here highlighted by music. In Rumi's world music has two parallels; one is "earthly" music, the music which accompanies eating, drinking and dance, and the other, "celestial" music. Traditionally, engaging with the kind of music that is suitable for festivity is a sin and regarded very negatively by Islamic jurisprudence. But even music that is of a more serious tone does not fare very highly. Rumi, it seems, did not look at the issue from the perspective of jurisprudence since he does not have a generally negative view of music; in fact he was accused of degrading himself to the triviality of music: "they say that from the sama' [ritual Sufi music and dance-like movement] respectability and nobility is belittled / [says I] nobility be all yours for love is my respect and my destiny" (Divan-e Shams, 1823.11). He does, however, take a negative stance on the earthly kind of music: "What is wine or music [sama] or sexual intercourse / that you should seek delight and profit there from?" (Book 5: 3580), while raising celestial music to great heights claiming it to be "the food of lovers" (Book 4: 742). It is noteworthy that he uses the same word in both instances. The word "sama," originally Arabic, means "to hear." In modern Persian the word is mostly used to refer to the Sufi ritual; Rumi, however, uses the word both in the meaning of music in general and the ritual Sufi music and dance. The fact that he uses the same word for two totally different kinds of music, implies that in comparison there is a difference of degree, not of essence. The difference being that the one is the music which appeals to the aware, reasoning self and the other that of the annihilated self in love. In Rumi, it is through the comparison of the first with the second that the former becomes degraded and is shunned.

The celestial music is in harmony with the inner being; it is a tune silently residing within man ready to be played. Love is its sole musician. As the flute has the potential to create beauty in sound so "We are as the flute, and the music in us is from you" (Book 1: 599). When the player starts playing, the flute has no other choice than to create harmonious melody and this is, perhaps, the fulfillment of its highest inner potential. When love plays the human melody, the result is an inner enchantment which, ultimately, needs a bodily outlet.

With the enlivening of the inner state of love, there follows an outward manifestation which for Rumi is, of necessity, the sama'; sama' is "an expression of his enraptured interior state which he, in most cases, could not control" (Schimmel, 1993, p.178). Nor did he want to. It was in this enraptured state that he, unlike all else who were "sleeping in their dark night of innocent ignorance," could experience the transparency of "the day revealed by the sun of love" (Divan-e Shams, 816.4). As with Donne, love in Rumi is a spiritual affair that ultimately comes back to the body and finds expression in the body. The sama', in which Rumi regularly engaged, was his love expressing itself through the body. Rumi had never before his encounter with Shams and his initiation into the world of spiritual love been intimate with either dance or music of any kind.

In Rumi's world, it is not only man who enlivens to dance in the rapture of love; nature is enraptured as well. Every single entity is, in correspondence with the all-encompassing love of the universe, already a part of the cosmic lure. "The visions of all forms are running toward the Vision / as iron shards drawn by a "magnet" (Divan-e Shams 33.1420). Rumi, seeing the world as illuminated by the light of the light of the heart, sees "all life in the search for the origin of its origin / drumming for [joy of] nothingness and clapping hands outwardly" (33.16). Some of Rumi's most enchanting poetry pictures the sama' of the natural world:

From the sweet melody of the Beloved's love, the earth was overwhelmed with excitement; In anticipation of union with the Beloved, the skies began an everlasting gyration. (131.6)

Have you heard that the nightingale came back from his [spiritual] excursion,

began gyrating in dance and became the sage of all birds?

Have you heard that today the tree branches heard new tidings from the flowers and began clapping? (782.3-4) The nightingale arrives playing the lute, and the cuckoo, calling $k u, k u$, And the other birds, celebrating happy fortune, such happy fortune. (1794.23) 
The integration of body and soul in love can also be seen from another perspective. The annihilated self in love is free of the burden of being autonomous. With this freedom from self comes unity with the universe in both poets. The lover, as Rumi describes himself in a qazal, is "believer," infidel, "Christian hermit," "the wine-dregs," "the cup-bearer," "the minstrel," "the harp, and the music," "the beloved," "the candle," "the drink" and "the joy of the drunken" (as cited in Arasteh, 2008, p.21). It is in this state that man connects to the "Universal Intellect;" he now has vision of this world and beyond: "This world is one thought from the Universal Intellect" (Book 2: 978). Being connected to its origin, he merges with the "one thought," creating a unified whole.

In "The Sunne Rising" Donne calls on the sun with a rhetorical question: "Looke, and tomorrow late, tell mee / Whether both the'India's of spice and Myne / Be where thou leftst them, or lie here with mee" and continues boldly with the assertion "Aske for those Kings whom thou saw'st yesterday / And thou shalt heare, All here in one bed lay." The following two lines establish a remarkable unity with all else: "She'is all States, and all Princes I / Nothing else is" (16-22). It is an amazing paradox that both poets having freed themselves from the temporal world in which they were confined, feel a harmonious unity with all entities of that very world. This is, perhaps, a parallel manifestation of the integration of soul and body in love. The soul, liberated from the material universe by love, returns to express its love through union with the bodies of that universe. Here again, spiritual ecstasy finds a corporeal outlet.

\section{Divine Jealousy in Love}

Finally, we reach the most visionary aspect of love in both poets: Divine jealousy. In Donne's "A Hymn To Christ At The Author's Last Going Into Germany" we encounter an earthly emotion in a heavenly domain. In this poem, Donne's God is a God that cannot tolerate his loving anyone else, a "jealous" God. In the third stanza Donne describes his God as one that does not control "The amorousness of an harmonious Soul" yet would have the love of that soul himself "as thou Art jealous, Lord" (18-20). Rumi's God is also jealous. The Divine Beloved is jealous of the lover's love for any other. In the words of Foruzanfar, interpreting Rumi's "The Tradesman and the Parrot," "when man centers his love on any entity [other than the Divine Beloved] Divinity subverts the focus of his love and annihilates it" (682). In this story at the point where the tradesman is lamenting the loss of the bird he dearly loved, Rumi attributes this loss to the jealousy of Divine love: "It was the jealousy of God and there is no device against God / where is a heart that is not in a hundred pieces by God's love?" (Book 1: 1712). A "heart" which is "in a hundred pieces" is on the surface meaning a heart in love, but it also carries the embedded meaning of a heart which has been overwhelmed, crushed. Rumi and Donne are now within vision of heavenly jealousy.

In both poets, human love reaches up to the Divine. It soars upward not satisfied with anything less than celestial heights. It reaches such sublime levels that even Divinity cannot tolerate its being directed toward anyone but itself. This, perhaps, was the most fulfilling love experience for the two poets: the experience of being the beloved of the Beloved.

\section{Conclusion}

In this paper, presupposing that great literature bestows true knowledge of human life through the unique inlet of heartfelt experience, we compared aspects of the love poetry of Jalāl al-Dīn Rūmī the most distinguished Sufi mystic and poet of the Persian language, and John Donne, the leading English poet of the Metaphysical school in an attempt to unveil the secrets of the most singular of human emotions: love. Having established that both poets attribute the highest office in the human domain to love, we argued most significantly that in both poets love polishes the human heart such that it becomes independent of reason and gives rise to a "new" self. We also argued that love creates perfect union between lover and beloved, that love defies time and place, and that in both poets, though ages and cultures apart, love incorporates both body and soul and is complete only in the harmonious integration of both. Finally, we showed how love takes both poets to the heights of Divine jealousy. Thus, we believe to have revealed the archetypal character of a human emotion that creates a world shared by two poets, who are themselves, worlds apart.

\section{References}

Arasteh, A. R. (2008). Rumi the Persian, the Sufi. Routledge, New York.

Bell, I. (2006). Gender matters: the women in Donne's poems. In A. Guibbory (Ed.), The Cambridge companion to John Donne. Cambridge University Press.

Brunetière, F. (1973). "European literature." In H. J. Schulz \& P. H. Rhein (Eds.). Comparative Literature: the Early Years. Chapel Hill: U of North Carolina P. 153-82.

Carlyle, T. (2010). The works of Thomas Carlyle (Vol. 28). Cambridge Library Collection - History. Cambridge University Press.

De Coster, M (2010). The collective unconscious and its archetypes. Satsang Press: Gent, Belgium.

Donne, J. (2004). John Donne: poems. PoemHunter.Com - The World's Poetry Archive, Classic Poetry Series.

Fayez, G. M. (1978). Mystic ideas and images in Jalal Al-Din Rumi and Walt Whitman. (Doctoral dissertation). Graduate College, The University Of Arizona. 
Flynn, K. G. (1995). Afterlife of a ladies' man: sacred and profane love in the poetry of John Donne and Leonard Cohen. (M.A. dissertation). Dalhousie University Halifax, Nova Scotia.

Hadfield, A. (2006). Literary contexts: predecessors and contemporaries. In A. Guibbory (Ed.), The Cambridge companion to John Donne. Cambridge University Press.

Lewis, C.S. (1960). The Four Loves. Helen Joy Lewis. Library of Congress Catalog Card Number: 60-10920.

Guibbory, A. (Ed.). (2006). The Cambridge companion to John Donne. (C) Cambridge University Press.

Mannani. M. (2004). Divine deviants: the dialectics of devotion in the poetry of Donne and Rumi (Doctoral dissertation). University of Alberta. ISBN: 0-612-96300-4

Mckevlin, D. J. (1973). A lecture in love's philosophy: Donne's Vision of the world of human love in the Songs And Sonets. (Doctoral dissertation). The University of New Mexico.

Plato. (n.d.). In Love. IMinds. (2014). iMinds Pty Ltd. p.1

Prawer, S.S. (1973). Comparative literary studies.

Rumi, J. (n.d.). Masnavī-yi Ma'navī. (R. A. Nicholson, Trans.). Retrieved from https://archive.org/details/Masnavi1Faen. Pdf file. - (n.d.). Divan-e Shams. (B. Furuzanfar, Ed.) Tehran: Negah Press, 1998.

Sagan, C. (1997). Contact. Pocket Books, Simon and Schuster.

Schimmel, A. (1993). The Triumphal Sun: A Study of the Works of Jalaloddin Rumi. Persian Studies Series; No. 8. State University of New York Press.

Shakespeare, W. (2004). Hamlet. D. Bevington \& D.S. Kastan (Eds.). Pearson Education, Inc.

Shakespeare, W. (2004). Love's Labour's Lost. D. Bevington \& D.S. Kastan (Eds.).Pearson Education, Inc.

Tennyson, A. (n.d.). "In Memoriam." Retrieved from: www.poetryfoundation.org/poems-andpoets/poems/detail/45336

Wilcox, H. (2006). Devotional writing. In A. Guibbory (Ed.), The Cambridge companion to John Donne. Cambridge University Press.

Wilde, O. (1952). Epigrams: An Anthology. Alvin Redman Publications.

\section{Notes:}

${ }^{1}$ All parenthetical reference citations based on "Book" division are from Rumi's Masnavi).

${ }^{2}$ All translations of the Divan-e Shams are by the authors.

${ }^{3}$ For Rumi, the substance of conception is light. The outside world is revealed by the light of the sun; the reasoning self sees by the light of the heart; and the annihilated self by the light of the light of the heart. The outside world is a world of forms and colors which, per se, have no apparent meaning. What is present, is the incoherent occupation of space by forms randomly colored and visible due to the light of the sun. "This outward [appearance] is from the sun and from [the star] Suha" (Masnavi, Book 1: 1125). There is, however, another light which illuminates the light of the sun and that is "the light of the heart." It is from the light of the heart that the world of forms and colors is conceived with new appreciation and illuminated with coherence: "the [illuminating] light of the light of the eye is the light of the heart" (Book 1: 1126). Thus, the meaning of the light of the eye - implying what the eye sees depends on the light of the heart: "the light of the eye is produced by the light of hearts" (Book 1: 1126). 